\title{
DRUMMOND: A METAMORFOSE EM DIREÇÃO À POESIA PURA
}

Cid Ottoni Bylaardt

Universidade Federal de Minas Gerais

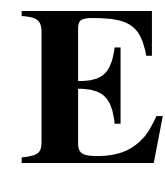

mbora a expressão poesia pura tenha sido usada diversas vezes na história da poesia, com as mais variadas conotações, remonta à década de vinte do século vinte o início de uma série de posicionamentos a respeito de purezas e impurezas dos poemas, e da possibilidade ou não - e em que circunstâncias - de existência de poesia pura. O abade Henri Brémond pode ser considerado o iniciador da celeuma; Poe, Baudelaire, Mallarmé e Valéry, citados por Brémond como "teóricos modernos da poesia pura", utilizaram o termo em acepções diferentes, o que impede que se chame o affair de "doutrina", como queria o abade francês. Brémond proferiu uma leitura intitulada La poésie pure em Paris, no ano de 1925, que acendeu a polêmica em torno do chamado "torneio da poesia pura". Os poetas citados por Brémond haviam mencionado a expressão poesia pura de maneira genérica, sem a intenção de transformá-la em bandeira de uma pretensa escola purista. Valéry, no auge do "torneio", declara ter usado o adjetivo puro de uma maneira não técnica, sem jamais pensar em "emitir uma teoria, ainda menos definir uma doutrina, ou, de forma alguma, considerar como heréticos todos aqueles que não concordassem comigo". 1

A associação feita por Brémond do nome de Valéry à sua "doutrina" de poesia pura teve um interesse eleitoreiro, o de preparar o campo para a eleição do poeta à Academia Francesa. Anos mais tarde, o próprio abade pronunciou um "esclarecimento", em que ele

${ }^{1}$ VALÉRY, 1957. p.1447-1463. 
admite que sua maior intenção era preparar o sucesso de Valéry entre os intelectuais, ou seja, sua fala teria tido uma intenção mais impura, e menos literária. Ele chegou ao ponto de reconhecer a própria incompetência para criar qualquer teoria poética: "Minha formação literária - poética - é completamente superficial, e sobretudo arcaica. (...) Não li mais do que 200 versos de Valéry, e não o releio". ${ }^{2}$

Para Henry Decker, a querela não passou de uma disputa sobre palavras mal definidas, título de um artigo em que o crítico contrapõe as razões de Valéry e Brémond. Entre os pólos antagônicos poesia-inspiração, na concepção bremondiana, e a poesia-fabricação valéryana, há uma infinidade de gradações que pretendem ou separar o puro do impuro, ou definir os limites em que termina a pureza e começa a impureza em poesia, ou determinar a impossibilidade ou, paradoxalmente, a necessidade da convivência desses elementos, na qual um é fundamental para que o outro apareça.

A poesia-inspiração, caminho para a pureza poética, na concepção de Brémond, teve seus defensores, como Jules Lemaître:

A idéia de poesia pura encontra-se, então, ligada àquela de inspiração, do gênio que sopra, de facilidade suprema e divina, um estado de graça que bastante naturalmente comparamos à comunicação com Deus. $^{3}$

O próprio Brémond admitia a precisão da linguagem poética, especialmente da poesia de Valéry, mas sem abrir mão do inefável em poesia:

A linguagem é precisa, ou então se torna verborrágica. Tanto a linguagem poética como a outra. Mas aquela tem algo de particular, de divino, isto é, sua própria precisão tem por objetivo único o de abrir, o máximo possível, as portas do mistério. ${ }^{4}$

${ }^{2}$ BRÉMOND citado por DECKER, 1962.

${ }^{3}$ LEMAÎTRE citado por DECKER, 1962.

${ }^{4}$ BRÉMOND citado por DECKER, 1962. p.4. 
A poesia-fabricação também tem seu halo de misticismo: a paixão de Mallarmé e Valéry pela técnica envolvem uma "mística da paixão e da precisão", que pode ser justificada pelo possível sentido da crença de Valéry, contida na pergunta de Thibaudet: "o bomo faber não tem direito à sua mística, assim como o bomo sapiens?"

Decker complementa ele mesmo:

A poesia pura seria um produto da mente ao invés de uma efusão da alma, verso dirigido unicamente à nossa inteligência (ou aos nossos sentidos), um mero jogo espirituoso, como alguns disseram. ${ }^{6}$

Paul Souday não aceita a "facilidade" da inspiração:

É certo que os modernos são, em geral, mais conscientes, mais refletidos, ou mais preocupados em levar ao público as suas reflexões. Mas essa nova moda coincidiu precisamente com o renascimento do lirismo. A poesia não perdeu nada com isso, e isso prova que ela não consiste em um puro instinto nem em não sabemos qual iluminismo fluido [outra vez Brémond] e estúpido. ${ }^{7}$

É evidente que o calor da batalha não costuma dar margem a relativizações. A questão da pureza ou da impureza da poesia, entretanto, exige uma definição de parâmetros, entre os quais possamos palmilhar a poesia e sua criação.

A obra objeto de nosso estudo de poesia pura será a primeira parte de Claro enigma, de Carlos Drummond de Andrade. Considerando a epígrafe da obra, que contém uma citação de Paul Valéry, - Les événements m'ennuient - e a introdução do editor, que situa o livro de Drummond como marco de poesia pura, faz-se necessário ouvir o poeta francês sobre suas concepções de pureza em poesia, para se tentar perceber como - ou se - esses conceitos se realizam no poeta itabirano.

5 THIBAUDET citado por DECKER, 1962. p.2.

${ }^{6}$ DECKER, 1962. p.7.

${ }^{7}$ SOUDAY citado por DECKER, 1962. p.11. 
Vamos tentar rever primeiro o que não é considerado poesia pura, na opinião de alguns teóricos, para, verificadas as impurezas, cotejá-las com o que remanesce de elemento puro. Henri Brémond, em que pese ter admitido a superficialidade e arcaísmo de sua cultura poética, foi bastante taxativo ao relacionar as impurezas da poesia:

Impuro é, portanto - oh, de uma impureza não real, mas metafísica! - tudo o que, em um poema, ocupa ou pode ocupar, imediatamente, nossas atividades de superfície, razão, imaginação, sensibilidade; tudo o que o poeta nos parece ter querido exprimir, e exprimiu com efeito; tudo o que dissemos que ele nos sugere; tudo o que a análise do gramático ou do filósofo tira desse poema; tudo o que uma tradução conserva. Impuro, é evidente demais, é o assunto ou sumário do poema; mas também o sentido de cada frase, a seqüência lógica das idéias, a progressão do discurso, o detalhe das descrições e mesmo as emoções diretamente excitadas. Ensinar, contar, pintar, causar arrepios ou provocar lágrimas, de tudo isso se desincumbiria muito bem a prosa, pois é seu objetivo natural. Impura, em uma palavra, é a eloqüência $(. . .)^{8}$

A julgar por essa relação de impurezas, o que sobraria de pureza num poema? As respostas são bastante metafísicas e nada palpáveis: o poema provoca uma metamorfose extraordinária nas palavras de todos os dias e de todo mundo, fazendo com que elas vibrem de repente com uma luz e uma força novas, ${ }^{9}$ realidade misteriosa e unificante, encantamento obscuro, magia mística, corrente elétrica...

Robert Penn Warren faz um lista do que, segundo vários críticos, teria de ser excluído da poesia que se pretendesse pura:

1. idéias, verdades, generalizações, "significado";

2. imagens precisas, complicadas, "intelectuais";

3. materiais desgraciosos, desagradáveis;

4. situações, narrativas, transições lógicas;

${ }^{8}$ BRÉMOND, 1926. p.5.

9 BRÉMOND, 1926. p.5. 
5. descrições exatas, detalhes realistas, realismo em geral;

6. mudanças de tom e de clima;

7. ironia;

8. variações métricas, adaptações dramáticas de ritmos;

9. o próprio metro;

10. elementos subjetivos e pessoais. ${ }^{10}$

Os elementos acima não foram dispostos em ordem de importância ou de freqüência de aparecimento em poemas de um modo geral. O primeiro item, entretanto, assume fundamental importância quando se relacionam idéias a palavras, com tudo que estas contêm de informações, de significados potenciais, de representações.

O ponto de partida da discussão sobre palavras e idéias, ou pelo menos a referência mais famosa ao affair é certamente a frase de Mallarmé: "On ne fait pas des vers avec des idées mais avec des mots".

Para Jorge Guillén, o dito é verdadeiro, o que não significa a eliminação das idéias:

¡Exacto! Y qualquiera interpretación formalista, aunque fuese del próprio Mallarmé, sería errónea. Porque la palabra del verso también es idea - con toda una constelación de asociaciones, alusiones, sugestiones. ${ }^{11}$

T. S. Elliot percebe a presença das idéias na poesia como um elemento de liame do leitor ao texto, algo necessário porém não determinante da qualidade de um poema:

O principal uso do "significado" de um poema, em um sentido comum, pode ser (aqui estou falando outra vez de algumas espécies de poesia, e não de todas) o de satisfazer um hábito do leitor, de manter sua mente distraída e quieta, enquanto o poema faz seu trabalho sobre ele: da mesma forma que o ladrão imaginário está sempre provido de um pedaço de carne suculenta para o cão-de-guarda. ${ }^{12}$

\footnotetext{
${ }^{10}$ WARREN, 1951. p.16.

${ }^{11}$ GUILLÉN, 1972. p. 77.

${ }^{12}$ ELLIOT citado por WARREN, 1951. p.17.
} 
Na linha da metáfora do pedaço de carne, numa abordagem que não dispensa o sentido lógico, Raïssa Maritain afirma que o significado, em poesia, é o que nos conduz ao sentido poético, que é espírito. A propósito dessa "ponte" que conduz à poesia (identificada com o sentido poético), Maritain cita Marcel Raymond:

A experiência prova que o sentimento do desconhecido só se propaga a partir do conhecido. ${ }^{13}$

O efeito da poesia no leitor (algo que é concebido nos misteriosos retiros do ser) é provocado, assim, tanto pela presença do sentido lógico quanto por certo ilogismo saboroso, que não éo sem-sentido, mas a superabundância de sentido. E assim conclui Maritain:

Assim é, acreditamos, a fonte do sentido poético, ele próprio livre e suficiente, sentido poético este que comporta inevitavelmente um sentido e uma falta de sentido lógico. ${ }^{14}$

O sentido, o significado, as idéias, para alguns, deviam ser excluídos de qualquer poesia que se pretendesse pura. Apenas num postulado puramente idealista, teórico, ou pretensamente metafísico, pode-se admitir essa exclusão. Um poema pode, sim, apresentar-se desprovido de sentido - hermetismo absoluto. Basta inventarem-se combinações de fonemas destituídos de conteúdo semântico. O resultado será um amontoado de sonoridades e ritmos de maior ou menor apelo auditivo, mas isso certamente não conduzirá a nenhum tipo de êxtase ou contemplação que ultrapasse um possível interesse momentâneo que possa manter sequer uma parcela do status conquistado pela arte da poesia em sua existência.

Algum sentido o poema há de apresentar, mesmo que seja a negação do ato de escrever, a constatação da impotência da palavra, como Un coup de dées. E esse sentido, que é uma idéia, é que intriga, instiga, provoca novas descobertas e conduz ao que Susan Sontag

${ }^{13}$ RAYMOND citado por MARITAIN, 1964. p.17.

${ }^{14}$ MARITAIN, 1964. p.15. 
chamou de sentido poético. Há, portanto, acima do nenhum sentido, o escasso sentido lógico, o algum sentido, que se pode graduar até o muito sentido lógico, que é o sentido da prosa. É evidente que o excesso de significado pode destruir um poema, ou impedir sua existência, mas a ausência de algum tipo de passagem para se descortinar o mundo que a poesia criou, subvertendo, destruindo e reconstruindo o que as grosseiras palavras do dia-a-dia dizem, pode ser a pá de cal na busca do sentido poético. A existência do significado é necessária, mas na dose exata de luz que seja mínima para permitir a entrada no reino da obscuridade necessária à contemplação, e máxima para que não ofusque a sensibilidade com a obviedade desencantadora.

Assim atuam os demais elementos impuros da poesia, numerados da segunda à décima posição no decálogo de Robert Penn Warren acima citado. Sua presença no poema é imperiosa, como pequenos figurantes que não podem aparecer muito, mas que devem contribuir para o brilho dos astros principais, mesmo que seja à custa do contraste. As estrelas "têm, para brilhar, necessidade da noite, e de não ficarem muito perto umas das outras". ${ }^{15}$

Já que não se pode falar de poema puro, pois a própria existência do poema pressupõe impurezas, a começar de seu elemento de fabricação, pode-se falar de poesia pura, encontrada em maior ou menor grau nos discursos poéticos, veiculada pelo contraste entre elementos puros e seus antípodas coadjuvantes, catapultas grosseiras para o vôo poético. Eis o óbvio: tanto mais puro será um poema quanto maior for a quantidade de poesia pura nele encontrada. Podemos encontrar índices de pureza nos poemas, como os que enumeramos abaixo. A enumeração, entretanto, e a constatação desses elementos no discurso poético não nos conduzem a explicações dos poemas, ou à aferição de seu grau de pureza ou de sua grandeza. Sempre haverá outras possibilidades de leitura de um texto poético, e essa inesgotabilidade é condição sine qua non para sua existência.

${ }^{15}$ CAILLOIS, 1944. p.3. 
Não obstante, atentemos para alguns "elementos de pureza" mais visíveis, ou "dizíveis", que permitam uma abordagem menos abstrata da questão da pureza dos poemas:

- menor aproximação possível com o mundo real e entrada no mundo poético

- maior identidade possível entre forma e conteúdo

- jogo com a lógica dos paradoxos, do impossível, do imponderável

- hermetismo proveniente de pressão interior

- valor absoluto das palavras

- linguagem sintética

- purificação/depuração da realidade pelos processos imagísticos

- arquitetura formal

- contenção e purificação das emoções

- predominância do sentido poético sobre o sentido lógico

A obra poética de Carlos Drummond de Andrade apresenta um momento que se afigura como diferente dos demais - anteriores e posteriores. É o livro de poemas Claro enigma, publicado em 1951, contendo poemas compostos entre 1948 e 1951, cuja primeira parte, "Entre lobo e cão", vai constituir o objeto principal de nossa investigação da poesia pura drummondiana. Talvez seja este o livro de Drummond menos elogiado pela crítica, menos conhecido pelo público, menos citado por exegetas, atacado mesmo por alguns, como veremos, mas é certamente o momento mais intrigante e instigante da obra do poeta.

Pouco antes da publicação de A Rosa do Povo (1945), Drummond já declarava sua preocupação com o trabalho sério na poesia, alertando sobre as facilidades de que alguns poetas modernistas usufruíam ao romperem com a técnica, e de certa forma repreendendo-se a si mesmo: 
Entendo que poesia é negócio de grande responsabilidade, e não considero honesto rotular-se de poeta quem apenas verseje por dorde-cotovelo, falta de dinheiro ou momentânea tomada de contato com as forças líricas do mundo, sem se entregar aos trabalhos cotidianos e secretos da técnica, da leitura, da contemplação e mesmo da ação. Até os poetas se armam, e um poeta desarmado é, mesmo, um ser à mercê de inspirações fáceis, dócil às modas e compromissos. Infelizmente, exige-se pouco do nosso poeta; menos do que se reclama ao pintor, ao músico, ao romancista... ${ }^{16}$

A abdicação da "poesia-para" em favor da "poesia-poesia", entretanto, foi mal compreendida por muitos críticos, entre os quais Emanuel de Moraes, que declarou sobre o Drummond de Claro enigma:

Uma terrível negação da arte de poetar que lhe impõe a madureza, contendo a mão do poeta e seus sortilégios de prestidigitador. (...) o seu verso ficou encasulado pelo formalismo métrico, desaparecendo o encanto de "ser apenas um compromisso claro entre o verso livre e a metrificação" (....) Demais, pode-se dizer que a sua própria imaginativa viu-se contida pelo rigorismo, por não se haver Drummond, na maioria das vezes, integralmente se adaptado aos critérios de composição tradicionais, inadequados que eram à expressão de sua poesia. ${ }^{17}$

É impossível não citar aqui, entre os que menos consideram Claro enigma, o famigerado estudo de Luiz Costa Lima, intitulado "O princípio-corrosão na poesia de Carlos Drummond de Andrade". $\mathrm{O}$ autor do artigo nutre uma evidente má-vontade para com esse livro de Drummond, manifestando seu desconforto com o fato de que ele se desvia totalmente do que vinha sendo feito até então na obra do poeta.

O artigo se baseia na proposta de um efeito corrosivo que permeia a poesia de Drummond desde Alguma poesia (1930), ora como advertência histórica e esperança de reconstrução, associada à

\footnotetext{
${ }^{16}$ ANDRADE, 1977. p.747.
}

${ }^{17}$ MORAES, 1977. p.26. 
idéia de luta, de corrosão ativa (corrosão-escavação), ora como cega destinação para um fim ignorado (corrosão-opacidade), e em muitos momentos imbricando-se mutuamente. A corrosão, então, para o crítico, "não se confunde com derrotismo ou absenteísmo. Ao contrário, no contexto drummondiano ela aparece como a maneira de assumir a História, de se pôr com ela em relação aberta" ${ }^{18} \mathrm{O}$ princípio que norteia o estudo de Costa Lima pressupõe, portanto, uma íntima convivência ou relação do poeta com a temática do real, do palpável, de uma tomada de consciência certeira da realidade.

A própria epígrafe de Claro enigma (Les événements m'ennuient, frase de Paul Valéry) começa por exercer uma ação desconcertante sobre o princípio defendido por Costa Lima, anunciando o que ele lamentaria ser uma "tendência em sufocar o princípio-corrosão pela opacidade absoluta" ${ }^{19}$ Preocupado em defender sua hipótese corrosiva a todo custo, o crítico culpa o poeta por se desviar dela no livro em questão, acusando-o de possuir um tom amaneirado ${ }^{20}$ de revestir-se de enganosa claridade, ${ }^{21}$ ressaltando, entretanto, que, como grande poeta, "na maioria dos casos Drummond consegue conter seu resvalar para a composição menor". ${ }^{22}$ Não conseguiu, entretanto, segundo o crítico, deixar de tangenciar a menoridade em poemas como "Memória" e "Chamado", citados nominalmente, e outros, de pequenez subentendida pelo rancor do crítico.

Os elementos que conduzem os poemas de Claro enigma em direção a uma maior pureza poética, no sentido que estamos considerando aqui, podem ser sintetizados na expressão de C. Lima: "a repressão da forma mais sensível de revelação do Tempo e da História". ${ }^{23}$ É evidente que para o crítico essa mudança não agrega

\footnotetext{
${ }^{18}$ LIMA. 1966. p.131.

${ }^{19}$ LIMA. 1966. p.174.

${ }^{20}$ LIMA. 1966. p.182.

${ }^{21}$ LIMA. 1966. p.176.

${ }^{22}$ LIMA. 1966. p.177.

${ }^{23}$ LIMA. 1966. p.176.
} 
virtudes; ao contrário, a novidade não deixa de vir a afetar a qualidade de poemas, mesmo inteiros. Embora admita a possibilidade de esta época de maturidade do poeta marcar "um despertar mais vivo de sua consciência artesanal", ${ }^{24} \mathrm{O}$ autor do artigo registra o aparecimento neste momento dos primeiros poemas formalizantes de Drummond, como uma possível concessão do autor à geração 45.

Em nossa concepção, a suposta renúncia do poeta ao Modernismo constitui, ao contrário, uma adesão a um Modernismo mais arejado e trabalhado, com propostas mais ousadas e, por isso mesmo, menos óbvias. Alguns anos depois de Claro enigma, o poeta declarou, em tom irônico:

Às 398 razões de incompatibilidade entre a arte moderna e o público poder-se-ia acrescentar mais esta: o público geralmente procura o assunto, enquanto a arte moderna o esquiva ou o elimina. ${ }^{25}$

Certamente a citada forma mais sensível de revelação do Tempo e da História é o que o crítico procurou - e não encontrou - na obra em questão, decepcionando-se.

O poema "Memória" - "passará de um poema formalizante?"26 - é emblemático da opinião do crítico, que apenas cita esse seu parecer sem se deter em nenhum aspecto elucidativo da afirmativa, como se o rótulo de formalizante bastasse por si para definir a qualidade do poema. Abstraindo-nos da carga pejorativa intencional do adjetivo, pensamos em formalizante como uma obra que revela um cuidado formal minucioso, que não se deixa tomar pelas facilidades do acaso ou pela adesão a circunstâncias e compromissos a que se espera que não falte o poeta.

O poema compõe-se de quatro tercetos de redondilhas menores com rima e ritmo absolutamente regulares, formando uma unidade monolítica:

${ }^{24}$ LIMA, 1966. p.177.

25 ANDRADE, 1977. p.847.

${ }^{26}$ LIMA, 1966. p.177. 


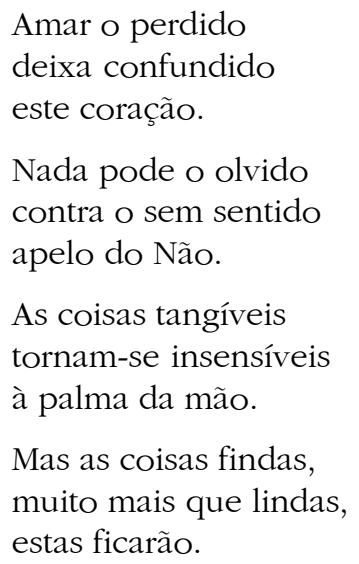

A unidade formal compõe-se com o sentido, aprisionando o jogo dialético das formas de negação do esquecimento, identificado com o real, que é destruição, em oposição à perpetuação da memória, do intangível, que é criação. Ao invés de princípio da corrosão, fazse presente o princípio da metamorfose, da construção do encantamento numa esfera além do tempo e da história, e que não os tem necessariamente como ponto de partida. Temos aí a palavra depurada, a emoção contida, o afastamento da realidade para se buscar outra com as mesmas palavras utilizadas na anterior. O poema reveste-se de intensa brevidade, em que a memória contemplada é evocada em imagens de pureza, serenidade, limpidez. O poeta segue um método consciente, rigoroso, a tendência é formalista sem dúvida, mas a poesia está presente, sem corrosão.

Outro poema de Drummond execrado pelo crítico é "O chamado", cujo assunto é o poeta Manuel Bandeira. Esse poema é comparado a "Ode no cinqüentenário do poeta brasileiro", de Sentimento do mundo (1940). A "Ode" é um belo poema sobre o poeta pernambucano, longo e emotivo, com uma apreciação bastante sentimental sobre o homem e sua poesia, repleto de referências intertextuais e metalingüísticas. O poeta homenageado é uma espécie de deus que perdoará e protegerá o mundo dos poetas que não são deuses, mundo cheio de pessoas humildes e às vezes fracas, oprimidas, que esperam poder se consolar com sua poesia, que 
estará sempre presente, perfeitamente inserida no tempo e na história, seguindo caminho diverso da arte de Rimbaud e Maiakovski. O poema é cheio de impurezas (no sentido "técnico" do termo) que contrastam com momentos de pura poesia.

"O chamado" de Claro enigma é o seguinte:

$\mathrm{Na}$ rua escura o velho poeta (lume de minha mocidade) já não criava, simples criatura exposta aos ventos da cidade.

Ao vê-lo curvo e desgarrado na caótica noite urbana, o que senti, não alegria, era, talvez, carência humana.

E pergunto ao poeta, pergunto-lhe (numa esperança que não digo) para onde vai - a que angra serena, a que Pasárgada, a que abrigo?

A palavra oscila no espaço um momento. Eis que, sibilino, entre as aparência sem rumo, responde o poeta: Ao meu destino.

E foi-se para onde a intuição, o amor, o risco desejado o chamavam, sem que ninguém pressentisse, em torno, o Chamado.

Na opinião de Costa Lima, a "Ode" tem a virtude de apresentar maior proximidade à mentação modernista, que cede lugar, em "O chamado", à polícia estrita da palavra. Este apresentaria um debilitamento progressivo da terceira estrofe até o final, que não consegue concluir, e, como para substituir essa impossibilidade, "o amaneirado se incorpora ao texto Drummondiano". ${ }^{27}$

${ }^{27}$ LIMA, 1966. p.182. 
O poema anterior exibe sua qualidade na apreensão polifacética do conjunto Bandeira-tempo, possibilitada pelo fato de que "a visão do poeta louvado se realiza em conjunto à visão do tempo que em comum eles pisam". ${ }^{28}$ Concluímos então com Costa Lima que a superioridade da "Ode" consiste no contato próximo à realidade e aos sentimentos grandiosos, que, ao invés de se debilitarem, vão adquirindo força até resvalar no divino.

O segundo Bandeira é evidentemente mais contido, mais condensado, o que o próprio crítico reconhece, mas não hesita em taxá-lo de amaneirado, o que nos parece uma contradição, a menos que o caso seja muito mais grave, de uma condensação formal tão vazia que apenas sobra lugar para o rebuscamento, o adorno.

Em confronto com a "Ode no cinqüentenário do poeta brasileiro", a depuração da linguagem em "O chamado" nos parece a realização antecipada da declaração do poeta logo após a publicação de Claro enigma:

A dificuldade inicial com que defronta o poeta de língua portuguesa, sendo esta, de natureza, analítica, e a poesia, sintética: trata-se de esconder o objeto, e não há cofre na sala; nem vão, nem subterrâneo dissimulado. ${ }^{29}$

Sem querer comparar a qualidade de duas peças absolutamente distintas, produzidas pelo mesmo autor em momentos diferentes e expectativas diversas, julgamos que o Bandeira de Claro enigma, sem a dimensão mítica do Bandeira de Sentimento do mundo, é o poeta do imponderável, o antigo lume que procura achar o brilho na noite escura, busca que se identifica com a do eu-poético. O brilho não se relaciona com o poder de encantamento do poeta, que os dois sempre tiveram de sobra, mas uma direção misteriosa, sem rumo certo, a que se pode chamar destino, que unifica o poeta e o fazer poético na ambigüidade da palavra chamado. Onde o

${ }^{28}$ LIMA, 1966. p.182

${ }^{29}$ ANDRADE, 1977. p.845. 
maneirismo? Certamente na ausência do princípio-corrosão, que para Costa Lima tem comparecimento obrigatório nos melhores poemas de Drummond, como um bruxo velado e escarninho. $\mathrm{O}$ veredito é taxativo sobre a influência do princípio e seu gênio difícil:

Mas também zeloso ou ciumento de seus direitos, onde é calcado deita fora a grandeza da peça, substituindo-a por um tom amaneirado e qualitativamente doloroso. Mais do que a imagem acima usada, o princípio-corrosão é, entretanto, semelhante ao gênio maligno da História, a se fazer presente pelo menos nos instantes mais poderosos..$^{30}$

A imagem do princípio-corrosão, ainda que possa ser contestada como condição para a existência de poesia maior em Drummond, é muito útil para auxiliar na exploração do que há de poesia pura em Claro enigma. Podemos deixar a corrosão de lado a partir de agora, já que ela está intimamente ligada ao tempo e à história, e às circunstâncias e acontecimentos, que o poeta aborrece. Não se pode corroer o abstrato e o ausente.

Essa renúncia ao tempo e à história aparece na obra de Drummond como um resultado do excesso de consciência histórica, que aflige a arte e a intelectualidade ocidentais deste século, como constata Susan Sontag:

Em pouco mais de dois séculos, a consciência da história transformou a si própria de uma libertação, um abrir de portas, uma iluminação abençoada, em uma carga quase insuportável de autoconsciência. ${ }^{31}$

O esvaziamento do princípio da corrosão em Claro enigma cede lugar ao que chamaremos de princípio da metamorfose, que preside o novo tempo da poesia drummondiana inaugurado nessa obra, e caracteriza a busca da pureza nesta fase. Esse princípio condutor da estética da metamorfose será examinado mais de perto, juntamente com outros elementos de afastamento da linguagem material, impregnada historicamente, na primeira parte da obra, "Entre lobo

${ }^{30}$ LIMA, 1966. p.184.

${ }^{31}$ SONTAG, 1982. p.22. 
e cão". Assim, a tentativa de purificação da linguagem em Claro enigma passa necessariamente por seu afastamento e negação da linguagem como agente de acumulação histórica. Daí a aceitação, de braços cruzados, de uma ordem outra de seres / e coisas não figuradas com que o poeta anuncia, já no primeiro poema, 'Dissolução', o clima de contemplação que perpassa a obra:
Escurece, e não me seduz tatear sequer uma lâmpada.
Pois que aprouve ao dia findar, aceito a noite.

A imagem do escurecer vai-se transformar em um símbolo, pela recorrência e persistência, na obra. A metáfora remete à idade madura do poeta - reforçada pela expressão Entre lobo e cão, que intitula a primeira parte: lusco-fusco, escurecer, boca da noite -, mas amplia-se na direção de um mundo novo, para o qual o ser é guiado e não lhe resiste. É a ruptura com o tempo e a história que se anuncia:
E com ela aceito que brote uma ordem outra de seres e coisas não figuradas. Braços cruzados.

Os sentimentos do mundo se esvaem, e esvaziam o universo das acumulações históricas, ampliando o espaço da nova ordem, que abriga outros habitantes, entre os quais possivelmente se inclui o poeta, o que comprova a imagem da pele na escuridão. Essa curiosa combinação de metonímia e metáfora da metamorfose reúne elementos antitéticos (pele branca $x$ noite negra) que se fundem e se desconstroem em outra dimensão: a pele, metonímia do ser, metáfora do poeta e da poesia, se funde com a escuridão, metáfora do desconhecido, e se derrete em um fim unânime.

A passagem é hesitante e encerra perdas e danos; enquanto o tempo que se vai é claro e agressivo, e portanto opressor, o que se descortina parece prometer a paz, mas como produto de destruição, de negação. A dimensão que abriga a ordem outra é tão indefinida que não comporta medição de tempo, mas é definitiva, não admite retorno. 
Merece destaque a desconcertante metáfora sinestésica da cor do galo. É a própria lógica do paradoxo: a cor do galo é uma elisão do óbvio e discursivo "a cor da madrugada no momento em que o galo canta”. O momento, com sua cor, representaria o retorno impossível à claridade, ao renascimento que exprime a extinção da ordem então vigente.

Outra inversão que produz o contraste do puro com o impuro é a intratextualidade com $A$ rosa do povo, rosa muito mais rica, cheia de encantos humanos e de libertação da consciência histórica, representativa da fase mais produtiva do poeta (conforme suas próprias palavras), e que agora é negada. Deve-se observar que o intratextual, bem como o intertextual, tem escassa recorrência em Claro enigma, exatamente pelo que esses recursos têm de compartilhamento com a cultura precedente e, portanto, pelo que contêm de impureza histórica. É evidente, aqui, o efeito de contraste do mundo impuro (rico e cheio de amor) com a busca da pureza de outra realidade.

O mesmo efeito é produzido pelo diálogo com "Vou-me embora pra Pasárgada" na referência à imaginação falsa demente. Entra aqui uma terceira dimensão no processo de negação e desconstrução. O mundo de Pasárgada, que nega o mundo real, também é negado na atual projeção. Em ambos se calam a palavra e a imaginação, e o corpo, vazio de tanta acumulação, se torna leve, sereno, tranqüilo.

A metamorfose do eu-lírico em direção à ordem outra é também uma exigência da busca de purificação da linguagem, ou seja, as palavras ordinárias devem-se despir de sua impregnação histórica para adquirirem nova existência em um mundo diferente, conforme afirma Raúl Castagnino:

Pero el poeta - porque es tal - inyecta a las palabras corrientes una virtud nueva, creadora y recreadora; y espera de ellas el servicio de que provoquen asociaciones, despierten sugestión, estimulen adivinaciones y, también - aunque esto sea, en cierto modo, indice situacional de un tiempo poético - que comuniquen una idea. Les proporciona (...) una capacidad de irradiación (...) que hace que, con escuchar o leer las palabras del poema, el receptor se encuentre, 
no más rico en información, con mayores conocimientos prácticos, sino tocado en lo profundo, por algo intangible, pero real y evidente. ${ }^{32}$

Um dos recursos mais utilizados por Drummond para fazer desprender das palavras tudo aquilo de que elas são capazes é emparelhar conceitos e imagens, jogar com a lógica dos paradoxos, dos impossíveis, dos imponderáveis. Arturo Rivas Sainz fala do caráter dual da metamorfose:

Metamorfosis y translación son afirmaciones y negaciones simultáneas: negaciones de principios de identidad y de contradicción, porque todo lo que se metamorfosea o se traslada, al mesmo tiempo que es, puesto que se puede cambiar, tiene la posibilidad de ser 'otra cosa' y, portanto, la contradictoria posibilidad de ser, puesto que es, y la de no ser lo que es, puesto que puede cambiar..$^{33}$

Assim, são índices de metamorfose e contradição em "Dissolução" antíteses como dia / noite; vazio / vasto; pele / escuridão; agressivo espírito / paz destroçada; mil anos / cor do galo; alma / corpo.

No poema "Remissão", o princípio da metamorfose se apresenta novamente: a poesia feita de circunstâncias é pasto dos vulgares, impureza contaminada das emoções da vida, tornada fria pela impregnação dos pesares e angústias. A poesia pura é aquela que não pretende ensinar, nem emocionar, nem informar nada; resta, portanto, o contentamento de escrever, no sentido valéryano da fabricação poética.

"Ingaia ciência" é o conhecimento que não dá prazer, a madureza que traz em si também a metamorfose, um acúmulo de história inoperante no caminho da destruição.

À negação do tempo e da história junta-se a negação do mito em "Legado". O inferno do mundo não se curva à lira de Orfeu; o poeta não engana o mundo, o mundo não engana o poeta, seu legado se situa em sua trajetória terrestre, nos poemas de mundo, na pedra no meio do caminho.

${ }^{32}$ CASTAGNINO, 1944. p.124.

33 SAINZ citado por CASTAGNINO, 1944. p.124. 
"Confissão" é despedida daqui (cego é quem se recusa a ver). A existência foi paradoxal, Dei sem dar e beijei sem beijo. Em direção à mudança, tesouros tangíveis desaparecem, os sinais do mundo não podem ser recompostos.

Curiosa é a presença do trocadilho: Não amei bastante sequer a mim mesmo, / contudopróximo. O trocadilho é um elemento impuro, por sua carga histórica e mítica; aqui, sua utilização é elemento de contraste deste ser excessivamente humano e impuro com o impossível ser amado é, o imponderável, o irreconstituível, o que é derrotado pelo mundo da técnica, conforme observa Octavio Paz:

Se o mundo como imagem se desvanece, uma nova realidade cobre toda a terra. A técnica é uma imagem tão poderosamente real visível, palpável, audível, ubíqua - que a verdadeira realidade deixou de ser natural ou sobrenatural: a indústria é nossa paisagem, nosso céu e nosso inferno. ${ }^{34}$

A inesperada metáfora do pássaro e do avião encena a inútil e terminada busca de pura liberdade azul e doida, que se destrói em confronto com o útil, o qual, por sua vez, será destruído ao deixar de ser útil.

Salvo aquele pássaro - vinha azul e doido que se esfacelou na asa do avião

Segundo Ortega y Gasset, citado por Octavio Paz, ${ }^{35}$ o homem deste século perdeu a imagem do futuro, com a morte de seus mitos e de suas histórias, o que implica a mutilação do passado. Conforme Paz,

Nosso tempo é o do fim da história como futuro imaginável e previsível. Reduzidos a um presente que se estreita cada vez mais, nos perguntamos: aonde vamos? Na realidade deveríamos indagar: em que tempo vivemos? ${ }^{36}$

\footnotetext{
${ }^{34}$ PAZ, 1982. p.319.

35 PAZ, 1982. p.323.

${ }^{36} \mathrm{PAZ}, 1982$. p.324.
} 
Essas indagações são lançadas de várias maneiras no poema "Perguntas em forma de cavalo-marinho". Nosso presente sem futuro está contido no tempo sem começo nem fim. O sucateamento do passado e a imobilidade circular do presente tecnicista frente à inutilidade deixa o homem perplexo diante do fim da história como processo previsível. Assim, as perguntas feitas no poema permanecem sem resposta, à espera de que os signos em rotação possam furar o bloqueio do desconhecido

A transformação se faz presente de novo em "Os animais do presépio", em que o eu-lírico incorpora a aparente leveza do reino animal, embutida no negrume geral, que rende homenagem ao nascimento do enviado. Ele é, afinal, o arauto da metamorfose para o desconhecido.

Em "Sonetilho do falso Fernando Pessoa", o eu-lírico recorre à impureza da intertextualidade para evocar a busca da pureza absenteísta do poeta português e sua atitude protéica de vestir várias peles e de se auto-negar na diversidade dos heterônimos e na ausência de comunicação com os valores convencionais.

A existência agônica da humanidade é vista através da impassibilidade contemplativa de um bovino em "Um boi vê os homens". A lógica, aqui, é deslocada para a visão do boi, que pertence a um outro mundo, de onde observa as impurezas humanas, entre as quais sua necessidade de expressar seus pobres sentimentos, emitindo sons absurdos e agônicos.

A contenção das emoções, a arquitetura formal e um certo hermetismo caracterizam "A tela contemplada", poema metalingüístico sobre a criação artística. A arte contemplada no poema é de tendência formalizante, a estética do apagamento e da brancura. Os mitos criados por esse novo artista se desprendem da terra e já recuam para a noite, símbolo do mundo não terreno, onde não cabem os sentimentos.

"Ser" é um poema que escapa da crítica contundente de Costa Lima, talvez por ter como assunto algo estritamente ligado à história terrena do homem: a geração de um filho. Entretanto, percebemos 
claramente aqui também o princípio da metamorfose. O filho que não foi feito existe abstrato, sem carne, sem nome, e habita um mundo próprio,

\author{
(além, além do amor) \\ onde nada, tudo \\ aspira a criar-se.
}

Um dos poemas mais emblemáticos de todo esse processo de desconstrução e de negação da linguagem em favor de sua depuração em Claro enigma é "Contemplação no banco". O ponto de partida é o prosaico banco de jardim ou de praça, em que o coração pulverizado sente o peso da existência no mundo e aspira a escaparlhe. O processo imagístico predominante nessa primeira estrofe é a metonímia, imagem mais pé-no-chão, mais próxima deste mundo. Contrapõe-se-lhe a metáfora da flor na segunda estrofe, que, calcária e sangüinea, pode ser um produto da humanização do espaço, produto que contém a possibilidade de ultrapassar a dimensão humana e o tempo da humanidade.

Essa flor será mentada e entoada para se opor às misérias da humanidade, e florescerá em um outro mundo, para um novo homem.

Na segunda parte, constrói-se o homem que nega, superior, a humanidade, que não pode ser chamado de irmão, porque a vida nova / se nutre de outros sais. A construção compreende uma integração de formas puras, um sublime arrolamento de contrários / enlaçados por fim. Esse homem, que se confunde com a poesia pura, afasta-se da linguagem e da arte deste mundo, do nosso vão desenho / e de nossas roucas onomatopéias, de nossos desgastados signos conspurcados pela acumulação histórica.

A terceira parte do poema tenta divisar o novo ser e a nova linguagem, que se desata do mundo em direção a uma nova existência, dissolvendo a cortina de palavras. Sua criação, entretanto, exige palavras que nunca foram inventadas, e o poeta se revela um místico sem Deus, incapaz de dizer o inefável, o que nem a literatura proporciona: 
Triste é não ter um verso maior que os literários,

é não compor um verso novo, desorbitado,

para envolver tua efígie lunar, ó quimera

que sobes do chão batido e da relva pobre.

"Cantiga de enganar" é o desengano do mundo e o engano no Mundo. Mais uma vez, o tema da desconstrução e da metamorfose para outra dimensão inefável e inexplicável. O tema se repete na insatisfação criadora em forma de soneto de "Oficina irritada" e na tentativa de se libertar de uma visão tecnicista do mundo em "Opaco", que resulta na impossibilidade de apreender o além do aqui.

"Sonho de um sonho" - três sonhos superpostos: elos / de uma infindável cadeia / de mitos organizados / em derredor de um pobre eu.

O sonho, com ser sonho, comporta a lucidez, que tem a função de concretar o fluido e abstrair o maciço. O eu-lírico encontra-se receptivo, magnético, com boa recepção do mundo, possibilidades claras convergindo em sua direção. O ouro do tempo (as glórias temporais, mundanas) provoca ambição, mas dá medo. E ainda sonhava pouco, havia muito mais. Ai de mim! Que mal sonhava.

Essa ordem lúcida comportava milhares de seres que eram ao mesmo tempo um, substância essencial e desejo de unidade. O eulírico converte-se no centro que produz raios, que ao mesmo tempo são centros e divergem para rotas não percorridas, embora anotadas em antigos portulanos e em indizíveis trajetórias.

Num momento o sonho se confunde com a realidade. De que é formado o sonho? Não de nossos desejos, não de nossos silêncios, mas do encanto das palavras,

mas do que vigia e fulge
em cada ardente palavra
proferida sem malícia,
aberta como uma flor
se entreabre: radiosamente.

O sonho do sonho apresenta vida própria, exterior ao eu-lírico; ele pode ser apreciado e contemplado externamente. O sonho- 
poesia não reflete nem imita a realidade; antes, transforma-a. O espelho é o diamante, a fonte de luz; o obscuro lado da vida é terra que se recupera pelo poder da poesia, libertando as sementes da perfeição.

Observe-se que neste poema o eixo da ordem outra invertese da obscuridade para a claridade, mas a falsidade do sonho faz prevalecer a treva,

$$
\begin{aligned}
& \text { nas paredes degradadas, } \\
& \text { na fumaça, na impostura, } \\
& \text { no riso mau, na inclemência, } \\
& \text { na fúria contra os tranqüilos, } \\
& \text { na estreita clausura física, } \\
& \text { no desamor à verdade, } \\
& \text { na ausência de todo amor, } \\
& \text { eu via, ai de mim, sentia } \\
& \text { que o sonho era sonho, e falso. }
\end{aligned}
$$

O princípio da metamorfose faz-se presente também neste poema, mas de uma forma diferente dos demais: na busca da claridade e na prevalência da obscuridade.

O último poema desta parte objeto de nossa investigação é "Aspiração", que condensa o desejo de poesia e de vida do poeta, em direção a uma pureza calma, sem sobressaltos de saltos da crueldade ao diamante. Emoções da vida, prazeres e sofrimentos mundanos, os sentimentos convencionais são negados em favor da aspiração maior.

Aspiro antes à fiel indiferença

mas pausada bastante para sustentar a vida

e, na sua indiscriminação de crueldade e diamante, capaz de sugerir o fim sem a indiferença dos prêmios.

Os demais momentos desta obra contêm também exemplos evidentes da busca da pureza, embora, talvez, não tão concentrados como na primeira parte. "Notícias amorosas" contém os mais belos poemas de amor da poesia de Drummond, com tudo o que contêm de impureza, satisfazendo o gosto de Luiz Costa Lima: 
Como grupo distinto e de qualidade ímpar destaca-se em Claro enigma a série constituída pelos poemas sobre o amor. Não nos parecem ser ocasionais a qualidade que os acompanha e a liberação do formalismo. O amor oferece a matéria pela qual o impuro, o misturado, o confuso, o mundo ainda pode ser alcançado. $\mathrm{O}$ absenteísmo da fase do poeta não retira o sal incluso no amor. ${ }^{37}$

Embora esses poemas de amor não constituam objeto deste estudo, convém constatar que eles não abusam do impuro, do misturado, do confuso. Antes, o amor é visto de uma perspectiva calma, sublime, serena, sem pilhérias, ironias ou arroubos. Eles contêm de pureza a despersonalização do lirismo amoroso, a depuração dos sentimentos, a atitude de contemplação que ultrapassa a fronteira entre o mundo de todo dia e o mundo criado pelo amor.

O mesmo se pode dizer dos poemas das seções restantes: "O menino e os homens", "Selo de Minas", "Os lábios cerrados" e "A máquina do mundo", que contêm muito de matéria impura: memória, homens, família, cidades. Não obstante, devemos insistir que o tratamento dado à matéria é que confere ao poema sua pureza - ou ausência dela. O assunto, conforme observa A. C. Bradley, não se encontra dentro do poema, e sim fora dele:

O assunto é uma coisa; o poema - matéria e forma unidos - uma outra. Sendo assim, é certamente óbvio que o valor poético não pode residir no assunto, e sim, inteiramente, no seu oposto, o poema. ${ }^{38}$

Não é nosso objetivo aqui discutir a qualidade desses poemas - algo indiscutível -, mas assinalar seu teor proposital de pureza como estética escolhida e trabalhada pelo autor. Não se pode deixar de assinalar, porém, que os poemas de Claro enigma realizam no leitor o que A. C. Bradley pecebe na poesia:

Sobre a melhor poesia flutua uma atmosfera de sugestão infinita. O poeta nos fala de uma coisa, mas nessa uma coisa parece estar contido o segredo de tudo. Ele disse o que queria, mas o

${ }^{37}$ LIMA, 1966. p.182.

${ }^{38}$ BRADLEY, 1963. p.5. 
sentido parece se esconder por detrás dele próprio, expandindo-se em algo sem fronteiras, ou somente visto como algo que, pressentimos, seria capaz de satisfazer não somente a imaginação, mas o todo de nós. ${ }^{39}$

Concluindo:

Ela é espírito. Vem não sabemos de onde. Não nos falará forçada, nem nos responderá em nossa linguagem. Não é nossa serva; é nossa mestra. ${ }^{40}$

Cremos, enfim, ter podido mostrar algo da pureza perseguida por Drummond em Claro enigma, e que reside em seu dualismo, em sua bipolaridade, que provoca tensão e confere força à poesia em sua metamorfose. Ela é pura no sentido de que não pretende ensinar, nem emocionar, nem informar nada; ela não se fundamenta em notícias do mundo, nem em intertextualidade. É pura no sentido de produzir um certo hermetismo essencial, provocado inicialmente pela própria negação da imagem habitual do mundo e do desejo de depuração verbal, da busca de superação da inevitável inequivalência entre o caráter analítico da linguagem usual e a necessária síntese da linguagem poética.

É evidente que algum hermetismo sempre advirá de uma poesia que busca deslocar-se de influências circunstanciais, através de um maior grau de abstracionismo que resulta em poemas de alto teor de pureza. Essa dificuldade de intelecção, entretanto, não deve prejudicar o convívio do leitor com a poesia, conforme observa Susan Sontag:

O espectador se aproximaria da arte como o faz de uma paisagem. Uma paisagem não exige sua "compreensão", suas imputações de significado, suas angústias e suas simpatias

(...) A uma tal plenitude ideal a que o público nada pode acrescentar, análoga à relação estética com a natureza, aspira uma grande parcela da arte contemporânea - através de várias estratégias de brandura, redução, desindividualização, alogicidade..$^{41}$

\footnotetext{
${ }^{39}$ BRADLEY, 1963. p.16.

${ }^{40}$ BRADLEY, 1963. p.16.

${ }^{41}$ SONTAG, 1982. p.23.
} 
Finalmente, tende à pureza essa poesia que constitui outro mundo, à parte, independente, completo, autônomo. Ser outra forma de vida não pressupõe que a poesia exija, para que compartilhemos de seu mundo, uma ruptura total e irreversível com o mundo real, embora exija um tipo diferente de experiência, uma imaginação contemplativa que produz em nós um resultado diferente dos que encontramos no dia-a-dia.

\section{Referências Bibliográficas}

ANDRADE, Carlos Drummond de. Poesia completa e prosa. Rio de Janeiro: Nova Aguilar, 1977.

ANDRADE, Carlos Drummond de. Claro enigma. Rio de Janeiro: Record, 1995.

BRADLEY, A. C. Poesia pela poesia. In: Leituras sobre poesia em Oxford. Trad. Sergio Alves Peixoto. London: Macmillan, 1963.

BRÉMOND, Henri. La poésie pure. In: La poésie pure. Avec un débat sur la poésie par Robert de Souza. Trad. Sergio Alves Peixoto. Paris: Bernard Grasset, 1926.

CAILLOIS, Roger. Impostures de la poésie. In: Les impostures de la poésie. Trad. Sergio Alves Peixoto. Buenos Aires: Sur, 1944.

CASTAGNINO, R. H. En torno de la poesía pura, sus señales y sus effectos. In: Fenomenología del poético. Buenos Aires: Sur, 1944.

DECKER, Henry W. Pure poetry. Trad. Sergio Alves Peixoto. Berkeley: University of California Press, 1962.

GUILLÉN, Jorge. Lenguage insuficiente: San Juan de la Cruz, o lo inefable místico. In: Lenguage y poesía. Madrid: Alianza Editorial, 1972.

LIMA, Luiz Costa. O princípio-corrosão na poesia de Carlos Drummond de Andrade. In: Lira e antilira. Rio de Janeiro: Civilização Brasileira, 1966. 
MARITAIN, Raïssa. Sentido e falta de sentido em poesia. In: Situation de la poésie. Trad. Sergio Alves Peixoto. Bruges: Desclée de Brower, 1964.

MORAES, Emanuel de. As várias faces de uma poesia. In: ANDRADE, Carlos Drummond de. Poesia completa e prosa. Rio de Janeiro: Nova Aguilar, 1977.

PAZ, Octavio. Signos em rotação. In: O arco e a lira. Rio de Janeiro: Nova Fronteira, 1982.

SONTAG, Susan. A estética do silêncio. In: A vontade radical. São Paulo: Companhia das Letras, 1982.

VALÉRY, Paul. Calepin d'un poète. In: Oeuvres, I. Trad. Sergio Alves Peixoto. Paris: Gallimard, 1957.

WARREN, Robert Penn. Pure and impure poetry. In: RAMSON, John Crowe (Ed.). The Kenyon critics: studies in modern literature from the Kenyon Review. Trad. Sergio Alves Peixoto. Cleveland: The World Publishing Company, 1951. 


\section{Resumo}

A obra poética de Carlos Drummond de Andrade apresenta um momento que se afigura diferente dos demais - anteriores e posteriores. É o livro Claro enigma, que contém poemas compostos entre 1948 e 1951. A primeira parte do livro, "Entre lobo e cão", vai constituir o objeto principal de investigação da poesia pura drummondiana neste artigo. Chamamos essa poesia de pura no sentido de que ela não pretende ensinar, nem emocionar, nem informar nada. É pura no sentido de produzir um certo hermetismo essencial, provocado inicialmente pela própria negação da imagem habitual do mundo e do desejo de depuração verbal. Tende, enfim, à pureza essa poesia que constitui outro mundo, independente, completo, autônomo. Ser outra forma de vida não pressupõe que a poesia exija, para que compartilhemos de seu mundo, uma ruptura total e irreversível com o mundo real, embora demande um tipo diferente de experiência, provocado pela imaginação contemplativa.

\section{Summary}

Carlos Drummond de Andrade's poetic work presents a moment that appears different from the others - earlier or later ones. It is the book Claro enigma, which includes poems composed between 1948 and 1951. The first part of the work, "Entre lobo e cão", is the main object of investigation about Drummond's pure poetry in this essay. We call this poetry pure in the sense that it doesn't intend neither to teach, nor to make emotions rise, nor to report facts. It is pure in the sense that it shows a kind of essential hermetical nature, caused initially by the very denying of the habitual image of the exterior world and by the desire of language depuration. In short, this poetry that creates an independent, complete and autonomous world tends towards purity. To be another kind of life doesn't mean that this poetry requires, for us to share its world, a total and irreversible breaking with the real world, although it demands a different kind of experience, brought about by contemplative imagination. 